\title{
Community Housing for the Elderly as a Source of Social Support and Prevention of Social Exclusion ${ }^{1}$ Adéla Mojžíšová, Dagmar Dvořáčková and Miroslav Barták
}

\begin{abstract}
:
Since the end of the 1980s, the concept of community housing for the elderly has been established abroad. The advantages and disadvantages of this alternative housing for the aging generation are discussed in the context of various theoretical backgrounds and practical approaches. The aim of the article is to offer a view of the advantages and disadvantages of this concept from the perspective of the inhabitants of these communities abroad. Nine semi-structured interviews were conducted with residents and one community housing manager in Austria, Germany, Denmark, and Sweden. The interviews were evaluated with the help of the Atlas.ti 7 program. On the part of the participants, community housing for seniors is evaluated mostly positively; according to their statements, the negatives result from problems related to socialisation within the community. The findings obtained during the interviews are in line with other previously conducted research. They fulfil the postulates about the advantages of community housing for seniors, and they also confirm the disadvantages already formulated in the literature. Considering all the verbalised advantages and disadvantages of community housing for the elderly in conversations, this type of housing can also be a welcome alternative for a certain part of the senior population in the Czech Republic.
\end{abstract}

Keywords: community, housing, co-housing, aging, seniors

\section{Introduction}

In the Czech Republic, the number of people over the age of 65 is growing in all regions. According to the Czech Statistical Office, the share of seniors in the population was $13.1 \%$ in 2001, in 2017 it was $19.2 \%$, and the estimate for 2050 is $28.6 \% .^{2}$ The increase in the population at this age in high-income countries is a consequence of an increase in life expectancy. The higher life expectancy is caused by a reduction in mortality. ${ }^{3}$ This situation and its expected development bring

$1 \quad$ This article is financially supported by the TA ČR program within the project Model péče o seniory v pobytových zařizeních v konceptu třistupnového bydlení (Model of Care for the Elderly in Residential Facilities in the Concept of Three-level Housing), TL 01000032.

2 (c) Český statistický úřad, Věková struktura populace se výrazně mění (on-line), available at: https://www.czso.cz/csu/czso/vekovastruktura-populace-se-vyrazne-meni, published 29 $9^{\text {th }}$ March 2019, cited $5^{\text {th }}$ May 2020.

3 WHO, World report on Ageing and Health, Luxembourg: World Health Organization, 2015, p. 3. 
a number of challenges. Both those who shape social policy and those to whom it is addressed respond to these challenges. New challenges and development opportunities arise, including diversity in experiencing old age, persistent social inequalities and stereotypes, and changing expectations. In summary, the overall context in which the aging population lives is changing. ${ }^{4}$ One of the important issues associated with the aging generation is meeting the needs of housing - from independent housing (through inter-generational housing) to housing (or accommodation) in the context of the system of social or health care services. Housing conditions and the location represent a significant factor in the quality of life of seniors as an important aspect of housing for the elderly population is its sustainability in the aging process. ${ }^{5}$ Important elements of housing that take into account the needs of an aging population are accessibility in the physical sense of housing comfort and safety, support services including assistance in everyday instrumental needs and, last but not least, socialisation mediating the full spectrum of social interactions in life of the elderly. ${ }^{6}$ An important concept that can be used to understand the issue of housing of the aging generation is the framework of 'housing pathways.' This concept, in comparison with the approach of 'housing career' or 'housing trajectory', implies non-linearity of housing options more. It also involves the possibility of finding alternative ways of the living environment (housing) which enable one to experience meaningfulness and happiness in life. ${ }^{8}$ One of these ways is also living within the community. Community as such and the feeling of community are other concepts that implicitly offer the possibility of a better life (this way of life is seen as better when compared to an isolated and lonely life, which is potentially related to individual living). ${ }^{9}$

\section{Community Housing for Seniors}

One of the housing options for seniors is community housing which, in some countries, represents a possible alternative of housing for the aging generation (less known in the Czech Republic). In this way of living, people organise their lives together, sharing common spaces such as a kitchen, lounge, dining room, laundry, gym, bike shed, or garden. However, the individual apartments preserve the privacy of the inhabitants. The key to success is the social focus of co-housing, the enthusiasm and sense of the co-owners for the community, and a very positive attitude towards social interaction. ${ }^{10}$ The issue of co-housing is closely related to the issue of power, respectively the fusion of control and care in modern institutions. ${ }^{11}$ The authors work with the concept of caring architecture and controlling architecture. ${ }^{12}$ According to these authors, it is clear that co-housing provides individualised care for the elderly where the privacy, autonomy, and dignity of clients are agreed. There are clearly separated private spaces from public ones in a network of seniors' relationships. Co-housing offers its seniors safe living in the community.

WHO, World..., p. 12.

5 Stephen FROCHEN and Jon PYNOOS, Housing for the Elderly: Addressing Gaps in Knowledge Through the Lens of Age-Friendly Communities, Journal of Housing For the Elderly 2/2017, p. 160.

6 FROCHEN, Housing..., p. 161.

7 David CLAPHAM, Housing Pathways: A Post Modern Analytical Framework, Housing, Theory and Society 2/2002, p. 63.

8 Outi JOLANKI and Anni VILKKO, The Meaning of a "Sense of Community" in a Finnish Senior Co-Housing Community, Journal of Housing For the Elderly 1-2/2015, p. 111.

9 JOLANKI and VILKKO, The..., p. 121.

10 Henrik LARSEN, Three phases of Danish cohousing: tenure and the development of an alternative housing form, Journal Housing Studies 8/2019, p. 1364.

11 Ebba HÖGSTRÖM, Caring Architecture Institutions and Relational Practice, Newcastle upon Tyne: Cambridge Scholars Publishing, 2017, p. 116.

12 Ibid., pp. 28-29. 
According to a number of studies, ${ }^{13}$ community housing is a factor in improving the quality of life of most of its inhabitants. This is through community activities, close social contacts evoking a sense of security, easy access to practical support, and the opportunity to participate in like-minded society. It is also important that life in community housing empowers older people, and makes old age better. ${ }^{14}$ Studies show ${ }^{15}$ that community housing for the elderly also has the potential for sustainable urban planning and it promotes social cohesion as well as the participation of future residents (owners in terms of private funding) in creating community housing projects (which often cannot be done without compromises).

The idea of community housing was applied in Denmark in 1987 for the first time. In this case, the Scandinavian model of inter-generational community housing was used as inspiration. ${ }^{16}$ The idea of community housing for an aging population spread to other countries subsequently. In Europe, for example, it came to Finland, the Netherlands, Austria, Germany, Poland, and France. Overseas, it expanded in the United States, Canada, Australia, and other countries. Within the community housing of seniors, The Gerotranscendence Theory of Aging ${ }^{17}$ is used in addition to the abovementioned. It focuses on the level of overlap, the social level, and the personal (personality) level. There, community housing has a figurative potential, for example, to reduce the fear of death, improve inter-generational connections, and increase self-acceptance and altruism. Rusovic and the team say that an advantage of community housing for seniors is the fact that it represents a solution for older people who do not want to live in institutions (such as residential social services) but who, at the same time, prefer the company of people of the same age. ${ }^{18}$

Based on a longitudinal study, Glass gives some reasons leading to the long-term use of this type of housing. They include establishing friendly relationships - the existence of friends in community housing, housing location, the aforementioned sense of community and mutual support, but also pride. Pride was associated, in one particular case, with the study participants who created the community. ${ }^{19}$ On the contrary, among the reasons that led to the act of leaving the community (apart from death) were the need for health care and support (which was not possible in community housing), the desire to be closer to family, and financial reasons (community housing can be both commercial and publicly supported). Another reason was the moment when the inhabitants of the community came to the conclusion that the community is not a suitable format of housing for them, and that life in the community was burdensome.

The aim of this article is to provide insight into the advantages and disadvantages of this type of housing on the basis of semi-structured interviews with residents and organisers of community housing for seniors in Austria, Germany, Sweden, and Denmark. This should provide a basis for potential consideration and application of this type of housing and the creation of space for further research in the context of the Czech Republic.

13 JOLANKI and VILKKO, The..., p. 111.

14 Ibid., p. 114.

15 Lidewij TUMMERS, The re-emergence of self-managed co-housing in Europe: A critical review of co-housing research, Urban Studies 10/2016, p. 2023.

16 Sherry CUMMINGS and Nancy P. KROPF, Forward for Active Older Adults, London: Springer, p. 9.

17 Ibid., pp. 15-16.

18 Katja RUSINOVIC et al., Senior Co-Housing in the Netherlands: Benefits and Drawbacks for Its Residents, International Journal of Environmental Research and Public Health 16/2019, p. 9.

19 Anne GLASS, A longitudinal Study at an Elder Cohousing Community: after 10 Years, Who left and Who's left?, Innovation in Aging 1/2017, p. 305. 


\section{Methods and Data}

\section{Research file}

The research group consisted of representatives of residents of community housing for the elderly. In total, approximately 50 community housing projects in Europe were addressed through electronic communication (based on an available database of these projects). ${ }^{20}$ Seven communities agreed to participate in the research.

\section{Participants and settings}

A total of nine semi-structured interviews were conducted in Austria, Germany, Sweden, and Denmark. The conversations took place face to face. We spoke to the inhabitant or caretaker of the building in the given community in the mentioned states. The basic characteristics of the participants are given in Table 1.

Table No. 1. Basic characteristics of interviews

\begin{tabular}{|l|l|l|l|l|}
\hline Location & Position & Age & Gender & $\begin{array}{l}\text { Length of con- } \\
\text { versation }\end{array}$ \\
\hline Austria I & caretaker & 42 & woman & approx. 2 hours \\
\hline Austria II & inhabitant & 69 & woman & approx. 2 hours \\
\hline Germany & inhabitant & 67 & woman & approx. 1 hour \\
\hline Sweden I & inhabitant & 68 & woman & approx. 2 hours \\
\hline Sweden I & inhabitant & 67 & woman & approx. 2 hours \\
\hline Sweden II & inhabitant & 70 & woman & approx. 2 hours \\
\hline Sweden II & inhabitant & 65 & woman & approx. 2 hours \\
\hline Denmark I & inhabitant & 48 & woman & approx. 2 hours \\
\hline Denmark II & inhabitant & 71 & woman & approx. 1 hour \\
\hline
\end{tabular}

\section{Methods}

A qualitative research strategy, with a semi-structured interview technique with interview lengths from one to two hours, was used.

\section{Interview scenario}

In addition to questions about the advantages and disadvantages of community housing, the interview scenario included questions related to the factors of aging in community housing, to the perception of the philosophy of community housing, and questions assessing the strengths, weaknesses, threats, and opportunities of community housing (from the point of view of the participants).

20 (C) Gemeenschappelijk Wonen voor gemeenschappelijk wonen in al haar vormen (on line), available at: http://www. gemeenschappelijkwonen.nl/community-addresses, cited $5^{\text {th }}$ May 2020. 


\section{Data processing}

The obtained data were processed by the method of open, axial, and selective coding, then by using the partial method of pattern recognition and contrasting, in the program Atlas.ti $7 .{ }^{21}$ Using open coding, basic codes were created. These were then categorised within code families based on context. However, classical axial coding within categories was not suitable for data interpretation, so the process of finding relationships between quotations was performed during code visualisation. For this procedure, the data were used separately according to the individual facilities which were then interconnected. Only later was the axial coding of quotations and codes between each other performed. After performing these axial coding steps for the individual areas, a subsequent re-coding was performed. During the latter, new codes were created specifying the meanings of the messages. These codes were additionally axially coded as subcategories. Specifically, these were methods with elements of card layout, methods of pattern recognition, and contrasting.

\section{Ethical aspects of work}

The research project was discussed and approved for implementation by the Ethics Committee of the Faculty of Health and Social Sciences of the University of South Bohemia in České Budějovice.

\section{Results}

\section{Perceived benefits of community housing}

As advantages and strengths of community living, the participants speak of: mutual tolerance and respect; a wide range of free time activities; financial operating costs sharing; modern living with an emphasis on social shared spaces; community life - joint decision-making, cooperation in the care of the house, garden; making life easier - cooking and shopping together, sharing some things - bicycles, lawn mowers, cars, garden tools, etc.; a group solution of possible problems; and prevention of loneliness. From the point of view of satisfying individual needs in community housing, the participants perceive feelings of security and friendship, and the opportunity to share their joys and sorrows with other people of similar age groups as essential. They highlighted the possibility of support if needed - neighbourhood assistance during shopping, illness, and when dealing with various life events.

The above is evidenced by one of the participants: A great advantage is in the social field. It is an opportunity to share community life and thus not suffer from old age or illness alone. I would emphasise our "community feeling". I would say I feel less lonely. It is easier to tolerate health problems when I am not depressed or lonely. If there is a problem in our community life, it will make me think about how to solve it. I can learn.' Furthermore, the benefits of community housing can be evidenced, for example, by the following statement: 'I would say that I can participate but I don't have to. I can keep the door closed or open all day and, for example, I can invite someone over for a drink when it's my birthday. Other perceived benefits are well illustrated by the following answer: 'Among the main benefits I would mention sharing. We can share ideas, things. Also, one has a good social life. For example, when you are not mobile enough, you have the opportunity to live a rich social life within the community. This is the biggest advantage. Another advantage is the common meals, borrowing things from each other, sharing a car. Actually, we share everything

21 C ATLAS.ti 7 Windows English, available at: https://atlasti.com/video-tutorials/atlas-ti-7-windows-english/, published 28 ${ }^{\text {th }}$ July 2015 , cited $5^{\text {th }}$ September 2020. 
(sleeping bags, tools, etc.). You don't have to buy all these things. This is a big advantage. We have a room here with things to share. There are things that someone doesn't need and you can take them. It is very convenient. It is something like an extended family system. It is a mix of friendship and family.' The possibility of peaceful coexistence is also mentioned. '... especially the peaceful coexistence with other inhabitants of a similar philosophy and interest. People here are never alone and have the support of others.'

\section{Perceived disadvantages of community housing}

The disadvantages and weaknesses mentioned by the participants are a certain loss of anonymity, the obligation to participate in joint activities and their large number, the obligation to adapt, but also differences in shared values.

This is evidenced by the answers of the participants: 'Collaborating in the community is not always easy. Not everyone is destined for this kind of life. It takes a lot of tolerance and patience.' One of the participants commented on a lot of activities as follows: 'A certain disadvantage may be that, according to some people, there are too many activities, a lot of actions. And they feel tired and don't want to take part in those events.' Another perceived disadvantage on the part of participants is securing trusted people in the administration of community housing. This is evidenced, for example, by the statement of one of the participants: 'Sometimes a problem can arise when you need to find trusted people to ensure administration.'

Other requirements that participants sometimes see as difficult to meet are: 'that residents must be willing to "work" on themselves, to participate in community work as there may be people who try to disrupt the community spirit. This is why we need constant readiness to discuss and solve problems. This can be stressful and frustrating sometimes.' The issue of the difference in values was also mentioned: 'Too large differences in values can lead to conflicts. If someone moves and for some reason is not interested in the community, it can be a problem.'

\section{Evaluation}

Most of the answers contain positive experiences with community housing (co-housing). In particular, the participants emphasised mutual support, cooperation, sharing, the opportunity not to suffer from loneliness, tolerance, and respect for others. The participants presented the joint implementation of various activities in which they support each other. On the other hand, they sensitively perceive the need for privacy and respect. This includes attentiveness to the specific needs of each individual who has chosen to live in this type of housing. Mutual neighbourhood assistance and inter-generational solidarity are appreciated significantly. The participants consider social interaction between the inhabitants and a lower risk of loneliness to be the most important strengths of this type of housing at senior age. On the other hand, they also mentioned perceived disadvantages and weaknesses connected to a certain loss of privacy or the need to constantly adapt to community life. 
Table No. 2: Evaluation of strengths and weaknesses of community housing

\begin{tabular}{|l|l|}
\hline Strengths & Weaknesses \\
\hline mutual tolerance and respect & loss of anonymity \\
\hline diverse range of free time activities & the need for active participation in joint events \\
\hline sharing of financial operating costs & difficulties in establishing relationships \\
\hline $\begin{array}{l}\text { modern living with an emphasis on shared social } \\
\text { space }\end{array}$ & disagreement if someone has a different lifestyle \\
\hline community life - joint decision making & inability to adapt to the majority \\
\hline cooperation in the care of the house, garden & too many different activities \\
\hline making life easier - cooking together, shopping & reluctance to work on oneself \\
\hline $\begin{array}{l}\text { sharing of some things - bikes, mowers, cars, } \\
\text { garden tools, etc. }\end{array}$ & the need for constant readiness to solve problems \\
\hline group solutions of possible problems & lack of interest in the community way of life \\
\hline prevention of loneliness & large differences in values \\
\hline feeling of safety & \\
\hline friendship & \\
\hline $\begin{array}{l}\text { sharing of joy and sorrow in the community of } \\
\text { one's peers }\end{array}$ & \\
\hline
\end{tabular}

\section{Discussion}

The participants state that the advantages and strengths of community housing are the fulfilment of the needs of quality housing, safety, interpersonal relationships, and life in a community of people with the same values and at the same stage of life. However, life within the community also brings them certain limitations which they perceive as problems and weaknesses. It is mainly a certain loss of anonymity, the need to participate in joint activities, and, in some cases, also problems concerning living with other members of the community. However, positive evaluations of community housing clearly outweigh the perceived disadvantages.

The findings obtained from the interviews are, in principle, in line with previous research, and fulfil the postulates about the benefits of community housing for seniors (as stated in current professional literature). Regarding the benefits of community housing for the elderly, the results of the interviews are in line with the current findings of Cummings and Kropf, ${ }^{22}$ or with the older works of Jolanki and Vilkko. ${ }^{23}$ The same disadvantages and weaknesses of community housing for seniors (which were mentioned by the respondents) are in the work of Glass. ${ }^{24}$ Even though the positive evaluations of community housing for seniors predominate (both in interviews and in the available literature), it should be kept in mind that it is not possible to choose one best way of living for seniors in the future only. ${ }^{25}$ Tummers also recommends that the individual needs of the senior and his family should be always taken into account. Also, the 
sustainability of the chosen way of cohabitation in old age, and the context of the environment should be considered. The model of community housing for seniors, as applied abroad, offers a possible and interesting approach to housing for this age group. It is based on a shared vision and values that have the potential to meet a number of needs of seniors in the area of housing. Co-housing appears to be more popular and sustainable than other forms of community housing. These are not described or analysed in this article. The interviews were conducted in countries with somewhat different historical and cultural traditions, as well as with different funding models for the implementation of community housing projects for seniors. Some communities (where the interviews took place) were not exclusively for the elderly population. Some of them represented an inter-generational community housing. This fact may have affected the responses of some participants. For the possible use of foreign experience in our country, it is necessary to adapt foreign knowledge to our domestic conditions and the corresponding needs of seniors. The challenge is also the active involvement of seniors in the planning and implementation of a community housing project. These matters make it suitable and attractive only for a certain part of the senior population. It is true that, due to its characteristics, this type of housing will be suitable and attractive for a part of the population of seniors only, both abroad and in our country. However, its eventual implementation will depend not only on the wishes of elderly citizens but also on the financial availability of this alternative used for senior housing abroad. The presented article has some limitations. It is mainly the fact that the results of interviews with individual participants cannot be generalised (both in general and between the individual countries where the interviews took place). The interviews were collected at a given point in time, and the interview scenario did not explicitly include all possible relevant questions. Other limitations are also related to the chosen methods of analysis and presentation of results.

\section{Conclusion}

Community housing (co-housing) of seniors is one of the possible housing alternatives for this important social group. The benefits perceived by the survey participants include a sense of security, mutual support and cooperation, a wide range of activities, the opportunity to share space with people at the same stage of life who recognise similar values, and thus to prevent feelings of loneliness and social exclusion. Perceived disadvantages include the need to adapt, the loss of anonymity, difficulties in interpersonal relationships, and the need to become used to life in the community. Considering all the advantages and disadvantages verbalised in the interviews, this type of housing can also be a welcome alternative for seniors in the Czech Republic. Further research should show interest in the given type of housing among current and future seniors in the Czech Republic.

\section{Contact}

\section{Assoc. Prof. Dr Adéla Mojžíšová}

University of South Bohemia in České Budějovice,

Faculty of Health and Social Studies

Institute of Social and Special-pedagogical Sciences

Jírovcova 24, 37004 České Budějovice

mojzis@zsf.jcu.cz 


\section{Dr Dagmar Dvořáčková}

University of South Bohemia in České Budějovice,

Faculty of Health and Social Studies

Institute of Social and Special-pedagogical Sciences

Jírovcova 24, 37004 České Budějovice

dvoracko@zsf.jcu.cz

\section{Dr Miroslav Barták}

University of South Bohemia in České Budějovice, Faculty of Health and Social Studies Institute of Social and Special-pedagogical Sciences Jírovcova 24, 37004 České Budějovice mbartak00@zsf.jcu.cz 